\title{
PEMANFAATAN LEBAH DAN PENGELOLAAN SAMPAH UNTUK EKONOMI RUMAH TANGGA YANG BERKELANJUTAN
}

\author{
Afiatry Putrika ${ }^{1}$, Deti Purwanti ${ }^{1}$, Adra Amalia Nur Ahlina, Nadhifa Tazkia Ramadhani, Ratna \\ Yuniati $^{1}$, Muhamad Sahlan' ${ }^{2}$, Kenny Lischer ${ }^{2}$, Apriliana Cahya Khayrani ${ }^{2}$, Amy Yayuk Sri \\ Rahayu $^{3}$, Nidaan Khafian ${ }^{3}$ dan Astari Dwiranti ${ }^{1 *}$ \\ ${ }^{1}$ Departemen Biologi, Fakultas Matematika dan Ilmu Pengetahuan Alam, Universitas Indonesia 16424 \\ ${ }^{2}$ DepartemenTeknik Kimia, Fakultas Teknik, Universitas Indonesia 16424 \\ ${ }^{3}$ Departemen Ilmu Administrasi, Fakultas Ilmu Administrasi, Universitas Indonesia 16424 \\ E-mail: astari.dwiranti@sci.ui.ac.id
}

\begin{abstract}
ABSTRAK. Lebah merupakan hewan dari kelas Insecta yang menghasilkan produk kaya manfaat, diantaranya madu, propolis, dan bee pollen. Lebah, khususnya yang tanpa sengat, dapat dibudidayakan oleh masyarakat perkotaan karena relatif aman. Tim Pengabdian Masyarakat Multidisiplin Universitas Indonesia, yang terdiri dari Fakultas Matematika dan Ilmu Pengetahuan Alam, Fakultas Teknik, dan Fakultas Ilmu Administrasi bekerjasama dengan komunitas "3bee" telah melaksanakan serial workshop secara daring dengan topik pemanfaatan lebah. Selain itu, tim pengabdi dengan "holistika institute" juga mengajak masyarakat untuk memanfaatkan sampah rumah tangga agar dapat diolah kembali menjadi produk yang dapat menghidupkan perekonomian rumah tangga. Serial workshop terdiri dari empat seri, masing-masing terdiri dari dua sesi. Topik yang disampaikan meliputi pengenalan lebah dan urban bee; tanaman pakan lebah dan produk lebah; pangan sehat dari lebah; pengolahan sampah organik dan anorganik; serta pemasaran dan kualitas pelayanan. Workshop diselenggarakan selama 4 Pekan mulai tanggal 10 Oktober hingga 7 November 2020. Selain pemaparan narasumber, terdapat pre-test, post-test, dan evaluasi kegiatan dari peserta pada tiap seri. Peserta workshop berjumlah 171 orang yang berasal dari berbagai wilayah di Indonesia. Sebagian besar berasal dari kalangan akademisi, komunitas penggiat lebah, serta pegawai dinas lingkungan dan kehutanan. Berdasarkan hasil evaluasi, sebagian besar peserta merasa sangat puas (rentang kepuasan 4,21-5,00) dengan workshop yang terselenggara dan berencana mengimplementasikan pengetahuan yang diperoleh dari workshop ini ( $87 \%$ ). Program pengabdian masyarakat multidisiplin ini dapat diduplikasi pada program lain sehingga penyampaian materi bersifat komprehensif. Program ini diharapkan dapat terus dikembangkan melalui program pendampingan sehingga lebah dan sampah dapat dimanfaatkan untuk meningkatkan ekonomi rumah tangga berkelanjutan di Indonesia.
\end{abstract}

Kata kunci: stingless bee; produk lebah; pengolahan sampah; pemasaran produk; pengabdian masyarakat multidisiplin.

ABSTRACT. Bees belong to Insecta class which produce valuable products such as honey, propolis, and bee pollen. Bee, especially the stingless ones, can be cultivated by the urban society since they are safe to be handled. The Universitas Indonesia multidisciplinary community engagement team, from the Faculty of Mathematics and Natural Sciences, Faculty of Engineering, and Faculty of Administrative Sciences, together with the "3bee" community, held an online workshop series on the topic of bee farming. In addition, the team with the "holistika institute" also share the information about waste management. The workshop has four series, two-session each. The topic of this workshop consists of the introduction of bee and urban bee, the plants for feeding the bees, the bee products, healthy food from the bee, organic and inorganic waste management, and the marketing and service quality. This workshop was conducted from October 10 to November 7, 2020. Information sharing, pre-test, post-test, and evaluation were carried out in each session. A total of 171 participants attended this workshop from various locations in Indonesia. Most of them were academician, bee-activist, and the staff of environment and foresty department. Most of the participants were satisfied with the workshop (with the satisfaction range of 4.21-5.00) and $87 \%$ participants are willing to implement the knowledge they gained. The multidisciplinary community engagement can be duplicated in other programs. This community engagement is expected to be further developed through a mentoring program thus the bee and waste can be used to increase the household economy sustainably in Indonesia.

\section{Keywords: stingless bee; bee products; waste management; product marketing; multidiscipline community engagement}

\section{PENDAHULUAN}

Lebah merupakan hewan dari kelas Insecta, berasal dari ordo Hymenoptera, yang berarti hewan dengan sayap selaput. Hewan tersebut berperan sebagai polinator yang membawa butir polen menuju bunga lain pada saat lebah mengambil nektar bunga. Produk yang dihasilkan dari lebah umumnya adalah madu sehingga disebut juga dengan istilah lebah madu (Lamerkabel 2011).

Secara umum, sebagian besar lebah memiliki struktur berupa sengat di bagian posteriornya. Namun, beberapa genus lebah ada yang tidak memiliki sengat (stingles bee), contohnya dari genus Trigona. Budidaya lebah tidak bersengat tersebut dapat meningkatkan perekonomian masyarakat karena beragamnya produk yang dihasilkan seperti madu, bee pollen, dan propolis yang memiliki nilai jual yang tinggi (Fadhilah dan Rizkika 2015).

Salah satu produk madu Trigona yang berasal dari kalimantan Timur dan kalimantan Utara memiliki rasa manis dan asam dengan $\mathrm{pH} 3-4$. Madu tersebut mengandung senyawa kimia dari kelompok tannin, alkaloid, flavonoid, triterpenoid, 
carotenoid, coumarin, saponin, karbohidrat, dan antioksidan yang berguna untuk kesehatan manusia (Syarfizal et al. 2020). Berdasarkan fakta tersebut, masyarakat mulai menjadikan madu sebagai salah satu suplemen kesehatan. Seiring dengan pandemi COVID-19 yang terjadi sejak petengahan tahun 2020, tingkat konsumsi produk lebah berupa madu oleh masyarakat mengalami peningkatan. Peternak lebah madu di daerah Rembang bahkan mengalami peningkatan penjualan sebesar 25 persen karena konsumsi madu masyarakat yang terus meningkat (Fadlil 2021). Melihat adanya peluang bisnis dari produk lebah tersebut, maka kegiatan budidaya lebah dapat menjadi salah satu alternatif kegiatan yang dapat meningkatkan ekonomi masyarakat.

Salah satu kegiatan budidaya lebah yang dapat dilakukan adalah budidaya lebah tidak bersengat (stingless bee). Budidaya lebah ini dapat dilakukan di daerah perkotaan karena sifat lebah tersebut yang tidak berbahaya. Selain itu kegiatan budidaya lebah tidak bersengat juga tidak perlu pemeliharaan yang intensif, tidak memerlukan peralatan khusus, dan sumber pakan dapat beragam.

Dalam skala rumah tangga, untuk meningkatkan pendapatan masyarakat, sampah organik dan anorganik yang dihasilkan sehari-hari juga dapat dimanfaatkan, diantaranya dapat mendukung budidaya lebah yang dilakukan. Sampah organik yang berasal dapat diolah menjadi pupuk, sehingga dapat menjadi sumber nutrisi untuk tanaman pakan lebah. Kegiatan pengabdian masyarakat terkait pengolahan sampah organik dan anorganik oleh Dwiranti et al. (2019) telah dilakukan di Desa Sarimukti, Garut. Pada kegiatan tersebut warga mengumpulkan sampah organik hasil sisa dapur dan sampah anorganik berupa kantong plastik. Berdasarkan kegiatan tersebut, warga Desa Sarimukti berhasil mengolah sampah baik organik maupun anorganik.

Selain budidaya lebah dan pengolahan sampah, tim pengabdi menilai perlu dilakukan juga edukasi kepada masyarakat untuk strategi pemasaran produk mereka. Syaifudin dan Normagiat (2020) menyebutkan permasalahan terkait pemasaran dan branding produk lebah madu menjadi salah satu masalah utama yang dihadapi oleh peternak madu Kelulut (Trigona sp.) di Kalimantan Barat. Adanya kondisi pandemi yang terjadi saat ini menyebabkan strategi pemasaran lebih mengarah pada pemasaran secara digital. Pemasaran secara digital atau digital marketing merupakan satu cara untuk memperkenalkan dan memasarkan sebuah produk atau jasa kepada masyarakat dengan memanfaatkan media digital/online. Maraknya media online seperti e-commerce dapat menjadi alternatif untuk dapat menjual produk olahan lebah dan sampah rumah tangga kepada masyarakat luas. Namun sebelum melakukan pemasaran produk secara online, masyarakat perlu mengetahui strategi dalam digital marketing.

Oleh karena itu tim pengabdian masyarakat multidisiplin Universitas Indonesia (UI) melakukan kegiatan serial workshop dengan judul "Pemanfaatan Lebah dan Sampah untuk Ekonomi Rumah Tangga yang Berkelanjutan". Kegiatan ini bertujuan untuk memberikan edukasi pada masyarakat untuk dapat melakukan kegiatan di rumah yang produktif dengan melakukan budidaya lebah tidak bersengat dan pengolahan sampah organik dan anorganik untuk dapat meningkatkan perekomonian rumah tangga di masa pandemi.

\section{METODE}

Kegiatan pengabdian masyarakat ini diselenggarakan secara kolaboratif antara bidang Biologi, Teknik Kimia, dan Ilmu Administrasi melalui metode Pendidikan masyarakat. Selain itu, tim bekerjasama dengan komunitas penggiat stingless bee dan manajemen pengolahan sampah, yaitu "3bee" dan "Holistika institute". Secara umum, tahapan pelaksanaan program dibagi menjadi tiga, yaitu sebelum, saat pelaksanaan, dan setelah pelaksanaan workshop. Tahap awal dimulai dengan proses diseminasi program dan rekrutmen peserta yang dilakukan dengan menyebarkan flyer ke beberapa media sosial dan komunitas pecinta lebah. Saat pelaksanaan, kegiatan workshop terbagi menjadi 4 seri dan dilaksanakan pada tanggal 10 Oktober-7 November 2020 melalui media daring Zoom. Dalam setiap sesi workshop, dilakukan pre-test dan post-test untuk mengukur pemahaman peserta sebelum dan setelah materi disampaikan. Pengisian pre-test, post-test, dan evaluasi dilakukan melalui laman google form. Hasil yang diperoleh kemudian diolah dan disajikan dalam bentuk grafik. Selain itu, peserta juga mengisi borang evaluasi untuk mendapatkan masukan dan saran untuk kegiatan selanjutnya. Tahap terakhir setelah pelaksanaan adalah proses pendampingan. Setelah pelaksanaan workshop, para peserta mendapatkan pendampingan langsung dari narasumber dan juga dapat berkomunikasi dengan peserta lainnya melalui platform komunikasi whatsapp group.

\section{HASIL DAN PEMBAHASAN}

\section{Karakteristik Peserta Workshop}

Berdasarkan hasil kegiatan workshop, tercatat jumlah peserta yang mengikuti kegiatan sebanyak 171 peserta. Gambar 1.A. menunjukkan sebaran 
daerah asal peserta, yang dapat dikelompokkan menjadi 6 kelompok daerah asal berdasarkan Pulaunya, yaitu dari Pulau Sumatera hingga Papua.

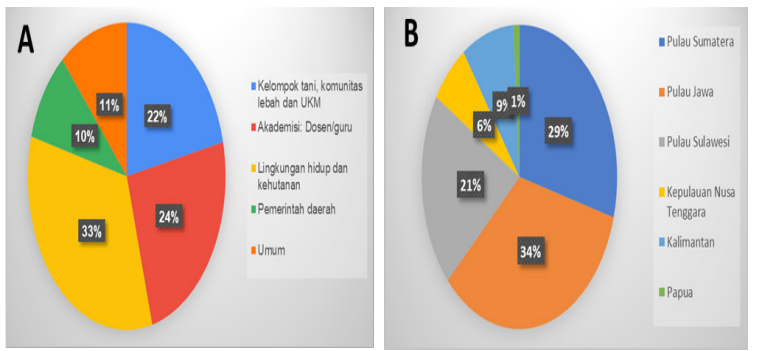

Gambar 1. Persentase perserta berdasarkan daerah asal dan bidang pekerjaannya.

Pulau Jawa merupakan daerah asal dengan jumlah peserta terbanyak, yaitu sebesar 34\%. Peserta dari Pulau Jawa sebagain besar berasal dari Banten, DKI Jakarta, Jawa Barat, D.I. Yogyakarta, Jawa Tengah, Jawa Timur. Setelah Pulau Jawa, Peserta dari Pulau Sumatera menyumbang jumlah peserta yang cukup banyak, yaitu sekitar $29 \%$. Sementaraitu, peserta yang paling sedikit berasal dari Papua berjumlah 1\%. Berdasarkan data tersebut, terlihat bahwa workshop yang dilakukan secara daring ini dapat menjaring peserta dan membagi ilmu kepada masyarakat secara luas dari berbagai daerah di Indonesia.

Selain dari daerah asalnya, bidang pekerjaan peserta workshop juga bervariasi, diantaranya adalah akademisi (guru dan dosen), kelompok tani, pegawai Dinas lingkungan hidup dan kehutanan, pemerintah daerah, dan peserta umum. Gambar 1.B. menunjukkan karakteristik peserta workshop berdasarkan bidang pekerjaannya.

Berdasarkan Gambar 1.B., terlihat bahwa peserta workshop didominasi oleh bidang pekerjaan lingkungan hidup dan kehutanan (33\%), baik dari pusat maupun daerah. Peserta dengan bidang pekerjaan dosen dan guru menempati peringkat ke-2 persentase bidang pekerjaan terbesar pada workshop tersebut. Sementara itu kelompok tani, komunitas lebah menempati posisi ke-3 jumlah persentase bidang pekerjaan peserta workshop terbanyak. Ketiga bidang tersebut masih berhubungan dengan tema dari workshop ini, yaitu budidaya lebah dan pengolahan sampah rumah tangga. Jumlah peserta umum sebesar $11 \%$ diketahui berasal dari ibu rumah tangga ataupun pegawai swasta. Bidang pekerjaan tersebut juga masih relevan dengan kegiatan workshop karena berkaitan dengan ekonomi rumah tangga yang berkelanjutan.

Variasi bidang pekerjaan ini memiliki potensi yang besar untuk pengembangan dan implementasi pengetahuan yang dibagikan dalam workshop. Peserta yang berprofesi sebagai pegawai pemerintah, dinas lingkungan hidup dan kehutanan, merupakan salah satu stakeholder yang dapat memiliki peran dalam meneruskan pengetahuan yang diperoleh kepada masyarakat luas di daerahnya maisng-maisng. Selain itu, peserta yang memiliki latarbelakang bervariasi ini dapat membangun jejaring dan saling berbagi informasi baik saat pelaksanaan bahkan hingga saat ini melalui proses pendampingan.

\section{Materi Budidaya Lebah}

Serial workshop dibagi menjadi empat seri dengan masing-masing seri terdiri dari dua sesi. Pada sesi 1 dan sesi 2, workshop difokuskan pada materi terkait budidaya lebah yang meliputi pengenalan lebah, pakan lebah, produk olahan dari lebah, dan ragam makanan sehat dari produk lebah. Narasumber yang dihadirkan untuk menyampaikan materi tersebut merupakan peneliti dan praktisi yang sudah lama bergerak dalam kegiatan budidaya lebah. Narasumber tersebut berasal dari Departemen Teknik Kimia, Fakultas Teknik Universitas Indonesia dan perwakilan dari komunitas "3bee". Tim pengabdi dari Departemen Teknik Kimia tersebut telah banyak meneliti mengenai propolis dari lebah tidak bersengat, diantaranya penelitian mengenai senyawa kimia dan aktivitas antioksidan propolis lebah Tetragonula. Aktivitas antioksidan tersebut dipengaruhi oleh kelompok senyawa fenolik yang berasal dari propolis (Pratami et al. 2018).

Pada materi pengenalan lebah, sebagai langkah awal dalam meningkatkan ketertarikan peserta workshop terhadap budidaya lebah, dijelaskan sejarah terkait budidaya lebah, pemanfaatan produk lebah, jenis-jenis lebah yang ada di Indonesia, kondisi budidaya lebah di Indonesia saat ini, hingga peluang budidaya lebah di Indonesia. Sejarah pemanfaatan lebah telah ada sejak zaman mesolitikum yang diketahui melalui lukisan dinding yang berada pada gua di Spanyol. Berdasarkan lukisan tersebut, manusia mulai memburu lebah dan mengumpulkan madu untuk dikonsumsi (Eroglu dan Yuksel 2020). Pemanfaatan lebah tersebut terus berlangsung dari waktu ke waktu dan menyebar sehingga ide melakukan budidaya lebah pun muncul. Saat ini budidaya lebah telah sangat berkembang dan bahkan dapat menjadi salah satu sumber mata pencahariaan. Budidaya lebah saat ini tidak hanya dilakukan untuk produksi madu melainkan produk-produk lebah lainnya seperti propolis, bee pollen, royal jelly, bee venom, dan bee wax (Lamerkabel 2011). Produkproduk tersebut telah banyak dimanfaatkan sebagai antimikroba (Susilo et al. 2009), imunomodulator, antioksidan (Halim et al. 2012), dan sebagainya. Jenis lebah yang saat ini dapat dibudidayakan juga sangat beragam, mulai dari jenis lebah bersengat hingga lebah tidak bersengat. Budidaya lebah tidak bersengat bahkan dapat dilakukan pada wilayah pemukiman karena cenderung tidak berbahaya. 
Teknik budidaya tersebut dikenal dengan istilah urban bee farming.

Budidaya lebah di Indonesia sendiri khususnya untuk lebah tidak bersengat sudah mulai dilakukan namun belum optimal. Hal tersebut ditunjukkan dengan nilai ekspor produk lebah dari Indonesia yang masih rendah dibandingkan dengan negara-negara lain seperti Vietnam, India, maupun China, padahal Indonesia memiliki kekayaan jenis lebah yang cukup beragam baik dari jenis lebah bersengat maupun lebah tidak bersengat seperti Apis cerena, Apis Dorsata, Apis hoshevinihovi, Apis migrocincita, Apis florae, Apis nullensis, Apis mellifera (Kementerian Kehutanan 2012), Tertagonula melanocephala, Tetragonula geissleri, Tetragonula fuscobalteata, Tetragonula laevicep (Sadam et al. 2016), dan Trigona Laeviceps (Putra et al. 2016). Selain itu, ketersediaan tanaman yang menjadi pakan lebah di Indonesia juga cukup melimpah. Tumbuhan yang biasa digunakan sebagai pakan lebah tidak bersengat dapat berupa tanaman buah, palawija, tanaman sayur, dan tanaman hias. Lebah tersebut memanfaatkan bagian tanaman berupa polen, nektar, dan resin (Priawandiputra et al. 2018). Berdasarkan penelitian Loeis 2019 lebah tidak bersengat Tetragona $\mathrm{cf}$ minor yang ada di FMIPA UI umumnya memanfaatkan polen dari tumbuhan Asystasia gangetica (rumput israel), Caesalpinia pucherrima (kembang merak), Carica papaya (Pepaya), Cocos nucifera (kelapa), Dendrophthoe pentandra (benalu), Mimosa sp. (putri malu), Morinda citrifolia (mengkudu), Lagestroemia sp. (bungur), famili Cyperaceae.

Kondisi pandemi yang terjadi saat ini menyebabkan meningkatnya kesadaran masyarakat terhadap kesehatan. Salah satunya dengan cara mengkonsumsi suplemen kesehatan seperti madu ataupun produk lebah lainnya. Hal ini menyebabkan meningkatnya permintaan terhadap produk lebah. Oleh karena itu, kegiatan budidaya lebah dapat menjadi kegiatan yang sangat bermanfaat untuk konsumsi pribadi maupun dikembangankan menjadi usaha.

Materi-materi yang disampaikan dalam workshop terkait budidaya lebah ini dievaluasi melalui pre-test dan post-test. Hasil pre-test dan posttest ditunjukkan pada Gambar 2 berikut.

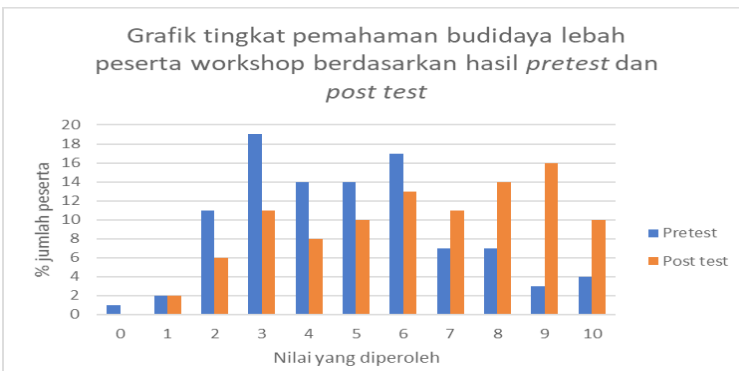

Gambar 2. Grafik tingkat pemahaman budidaya lebah peserta workshop berdasarkan hasil pre-test dan post-test.
Berdasarkan hasil pre-test dan post-test yang diberikan, terdapat peningkatan pemahaman peserta terkait budidaya lebah dari sebelum dan sesudah mengikuti workshop. Hal tersebut ditunjukkan dengan meningkatnya persentase jumlah peserta yang memperoleh nilai diatas 7 pada post-test $(10-16 \%)$ dibandingkan dengan pre-test (3-7\%). Pemberian edukasi dapat menjadi salah satu cara untuk meningkatkan pemahaman masyarakat terhadap suatu hal.

Secara umum peserta telah mengetahui hal-hal dasar yang diperlukan untuk memulai melakukan budidaya lebah seperti ketersediaan pakan, kondisi lingkungan, dan jenis predator yg ada. Peserta bahkan dapat menyebutkan jenis tanaman di sekitar yang dapat dimanfaatkan sebagai pakan lebah. Sebagian besar peserta juga sudah mengetahui produk lain selain madu yang dapat dihasilkan dari lebah yaitu propolis, bee pollen, royal jelly, bee venom, dan bee wax. Namun, pengetahuan tersebut tidak didukung dengan pengetahuan mengenai cara/teknik untuk memperoleh ataupun mengolahnya. Maka dari itu, selama kegiatan workshop, peserta lebih banyak berdiskusi terkait hal tersebut. Meskipun pemberian materi terkait budidaya lebah dilakukan secara daring, namun peserta dapat menerima materi dengan baik dan beberapa peserta bahkan mulai mengaplikasikan ilmu yang diperoleh dengan mulai melakukan kegiatan budidaya lebah tidak bersengat (Gambar 3). Pelatihan budidaya lebah pernah dilakukan sebelumnya oleh Sebayang dkk. tahun 2017 untuk meningkatkan pendapatan serta kesejahteraan petani di Desa Sumberejo, Kecamatan Merbau, Kabupaten Deli Serdang.

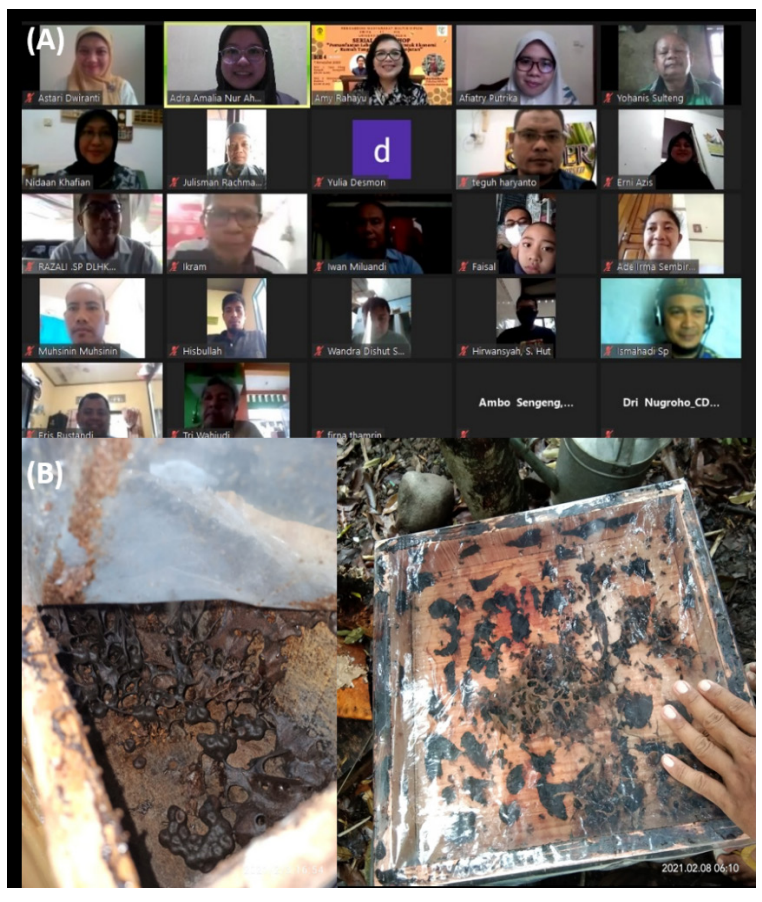

(Sumber: Dokumentasi peserta workshop).

Gambar 3. Kegiatan workshop daring (A) dan Hasil kegiatan budidaya lebah yang dilakukan peserta workshop (B) 


\section{Materi Pengelolaan Sampah}

Selain budidaya sampah, workshop ini juga mengangkat topik pengelolaan sampah untuk mendukung ekonomi rumah tangga berkelanjutan. Penyampaian materi dilakukan oleh tim dari Fakultas Matematika dan llmu Pengetahuan Alam bekerja sama dengan "Holistika Institute". Sampah biasa dihasilkan oleh aktivitas sehari-hari di rumah dan memiliki potensi yang besar untuk dimanfaatkan, meskipun pada umumnya dibuang begitu saja. Berdasarkan riset dari Sustainble Waste Indonesia, 24\% sampah di Indonesia masih tidak dikelola, 69\% berakhir di tempat pembuangan akhir (TPA) dan hanya $7 \%$ yang sudah di daur ulang. Pembuangan sampah dari rumah hingga saat ini masih dalam tataran pemindahan dari satu lokasi ke lokasi lain. Setiap harinya, 15 juta ton sampah yang tidak dikelola menyebabkan kerusakan lingkungan. Padahal, ketika sampah rumah tangga dapat diolah dengan baik, sampah tersebut tidak hanya mengurangi masalah yang lebih besar di masyarakat, tetapi juga dapat menjadi salah satu sumber penghasilan keluarga. Dalam workshop ini, pengelolaan sampah disampaikan dalam dua seri khusus, yaitu seri pengolahan sampah organik dan seri pengolahan sampah anorganik.

\section{Pengolahan sampah organik}

"Di setiap sudut rumahku berkah" merupakan topik yang diusung dalam sesi pengolahan sampah. Pemaparan materi dimulai dengan penyampaian kondisi saat ini terkait pengelolaan sampah di Indonesia. Sampah organik menempati persentase tertinggi yang dibuang setiap harinya yaitu $60 \%$ dibandingkan sampah lainnya seperti plastik (14\%), kertas $(9 \%)$, logam $(4,3 \%)$, serta bahan lainnya seperti kaca dan kayu (12,7\%). Sebagaimana sampah lainnya, hingga saat ini penanganan sampah masih berkutat pada pemindahan dari satu lokasi ke lokasi lain, belum sampai pengolahannya. Adapun solusi penanganan sampah dapat dilakukan dalam skala terkecil di keluarga, mulai dari pemilahan sampah yang dapat dilakukan di rumah masing-masing. Sampah organik terutama, dapat diolah mandiri menjadi berbagai produk yang lebih bernilai. Program pengabdian masyarakat dalam pengelolaan sampah sudah diimplementasikan di Kabupaten Garut (Dwiranti et al. 2019).

Beberapa kendala yang menjadi hambatan dalam mengelola sampah secara mandiri di rumah diantaranya adalah rendahnya kesadaran untuk mengelola sampah, framing negatif terhadap sampah, minimnya pemahaman mengenai baik buruknya sampah, cara penanganan yang keliru, serta tidak adanya keterampilan dalam mengolah sampah menjadi produk yang bermanfaat. Untuk menghadapi hambatan tersebut, berbagai hal dapat dilakukan dengan adanya kerjasama dari berbagai stakeholders, termasuk akademisi, pemerintah, organisasi yang bergerak di bidang lingkungan, serta masyarakat luas. Penyelesaian masalah pengelolaan sampah dapat diatasi dengan beberapa pendekatan seperti pengetahuan (kognitif), sikap (afektif), dan keterampilan (skill). Dalam skala rumah tangga, pengelolaan sampah yang dilakukan sedikit demi sedikit, mulai dari yang kecil dan dekat, secara berulang, dengan cara menyenangkan, ikhlas dan menikmati proses merupakan enam prinsip yang dapat dilakukan untuk mengubah paradigma tentang sampah dan pengelolaannya.

Sampah organik merupakan sampah yang berasal dari makhluk hidup dan memiliki sifat mudah membusuk/terurai dalam waktu singkat. Secara umum, sampah organik dapat dikelompokkan menjadi tiga, yaitu organik hijau (sayuran, buah, sisa nasi, kotoran ternak, dll.), organik coklat (kertas, dus, rumput kering, serbuk gergaji, jerami, dll.), dan organik merah (tulang, daging, lemak, dll.). Sampah organik mudah membusuk sehingga penanganannya perlu disegerakan sebelum menimbulkan permasalahan seperti bau.

Sampah organik dapat diolah menjadi beberapa produk yang memiliki nilai lebih, diantaranya adalah menjadi kompos, mikroorganisme lokal (MOL), ecoenzyme, dan pakan ternak. Dalam workshop ini, detail prosedur pembuatan produk-produk olahan sampah organik tersebut disampaikan kepada peserta. Tidak hanya selama pemaparan materi, tetapi modul untuk pembuatan masing-masing produk tersebut juga diberikan kepada peserta. Hal ini dilakukan sebagai salah satu langkah untuk mentransfer pengetahuan secara rinci sehingga peserta dapat menerapkannya secara langsung di rumah masing-masing atau bahkan bagi peserta yang bekerja di dinas pertanian, lingkungan, perkebunan, juga komunitas dapat menyebarkannya lebih luas lagi kepada masyarakat lainnya. Dalam masing-masing modul dijabarkan secara rinci alat bahan serta setiap tahapan yang harus dilakukan untuk mengolah sampah organik tersebut.

Salah satu produk pengolahan sampah organik adalah pupuk kompos. Modul yang disediakan tidak hanya berisi tentang satu metode saja, tetapi berbagai metode yang dapat dilakukan untuk mengolah sampah organik termasuk komposter aerob, hamparan (masal), Takakura, dan biopori juga disampaikan. Hal ini diberikan supaya peserta/ masyarakat dapat mengadopsi metode mana saja sesuai dengan kondisi masing-masing. Dikaitkan dengan budidaya lebah, pupuk yang dihasilkan dapat berperan untuk tanaman pakan lebah, sehingga budidaya lebah dan pengolahan sampah dapat saling menunjang. 
Untukmengevaluasipengetahuandan perubahan pola piker peserta terkait sampah, dilakukan pre-test dan post-test. Beberapa pertanyaan terkait pandangan tentang sampah, aturan yang berlaku, klasifikasi sampah, dan sebagainya. Berdasarkan hasil yang diperoleh, terlihat adanya perubahan positif jawaban sebelum dan sesudah materi disampaikan. Beberapa pertanyaan dan hasil pre-test dan post-test ditunjukkan pada Gambar 4 berikut.

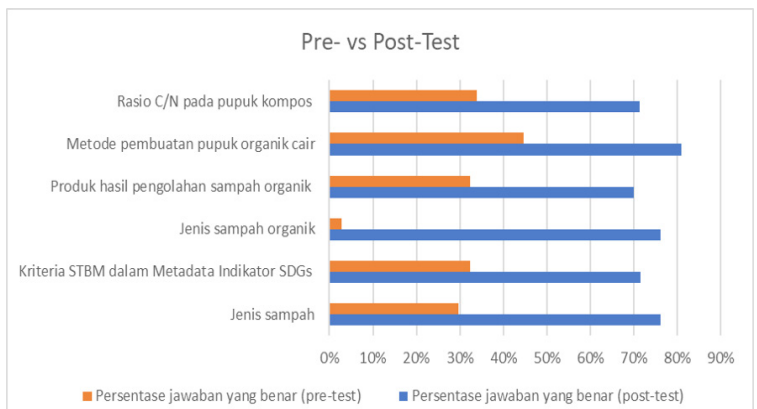

Gambar 4. Perbandingan persentase jawaban benar sebelum dan setelah penyampaian materi tentang pengolahan sampah organik.

Berdasarkan data di atas terlihat adanya peningkatan pemahaman peserta setelah materi disampaikan dalam workshop terkait pengolahan sampah, khususnya sampah organik. Setelah mengikuti workshop, terlihat bahwa lebih dari $70 \%$ jawaban yang benar dari peserta. Nilai ini meningkat dibandingkan sebelum mengikuti workshop.

Selain beberapa pertanyaan di atas, peserta juga ditanyakan pendapat mengenai sampah, sebelum dan sesudah pemaparan materi. Berdasarkan data, terdapat perubahan pendapat peserta yang awalnya menyebutkan bahwa sampah tersebut kotor, jijik, dan hal negatif lainnya $(68,9,9 \%)$ menjadi bersih dan membawa manfaat (81\%). Adanya perubahan pandangan terhadap sampah merupakan modal awal yang dibutuhkan untuk memulai adanya pengelolaan sampah, dimulai dari skala rumah tangga. Adanya perubahan paradigma ini terus diasah dengan adanya panduan pengolahan sampah dengan disediakannya modul pengolahan sampah yang dibagikan kepada peserta, hingga diskusi yang berkelanjutan antara pemateri dan peserta maupun sesama peserta melalui platform media komunikasi yang ada hingga saat ini.

\section{Pengolahan sampah anorganik}

Selain pengolahan sampah organik, peserta workshop juga diberikan materi mengenai pengolahan sampah anorganik pada seri keempat sehingga pemahaman mengenai pengolahan sampah lebih komprehensif, meliputi organik dan anorganik. Materi yang disampaikan meliputi pengenalan jenis-jenis sampah anorganik, kode plastik dan informasi daur ulangnya, hingga produk-produk hasil pengolahan sampah anorganik yang dapat diproduksi dari masing- masing jenis sampah anorganik yang dipaparkan sebelumnya.

Salah satu produk yang umum dihasilkan dari pengolahan sampah anorganik adalah berbagai kerajinan tangan berbahan dasar plastik. Produk rajut dari limbah kresek misalnya, dapat didaur ulang menjadi berbagai karya seni, termasuk yang bertemakan lebah. Jika dikaitkan dengan topik sebelumnya mengenai budidaya lebah, maka produk olahan ini dapat menunjang budidaya lebah khususnya dalam rangka merancang suatu program eduwisata bertemakan lebah. Kombinasi antara budidaya lebah dengan upaya pemasaran produk kerajinan bertemakan lebah yang berasal dari daur ulang sampah anorganik dapat menunjang ekonomi warga.

Selain produk daur ulang berupa kerajinan tangan, sampah anorganik juga dapat diolah menjadi berbagai produk bermanfaat lainnya seperti bahan bakar, paving block, media tanam (setelah dilakukan fermentasi dengan mikroorganisme lokal), dan sebagainya. Kegiatan pengolahan sampah anorganik ini akan lebih efektif lagi apabila dilaksanakan dalam suatu komunitas. Sebagaimana dilaporkan oleh Suheryanto dkk (2012), salah satu strategi yang dapat diterapkan untuk meningkatkan efektivitas pemanfaatan sampah adalah dengan pemberdayaan masyarakat (community empowerment).

\section{Pemasaran dan Pelayanan}

Sesi terakhir workshop membahas mengenai pemasaran, materi terkait digital marketing, dan kualitas pelayanan yang disampaikan oleh tim dari Fakultas Ilmu Administrasi. Menurut American Marketing Association (AMA), pemasaran merupakan suatu proses perencanaan dan pelaksanaan konsepsi, penetapan harga, promosi, dan distribusi ide, barang, atau jasa untuk menciptakan pertukaran yang menguntungkan bagi individu dan organisasi. Terdapat empat hal yang perlu diperhatikan dalam pemasaran, yaitu product, price, place, dan promotion (Kingsnorth 2016). Oleh karena itu, selama workshop peserta diberi penjelasan mengenai pentingnya komponen-komponen tersebut bagi keberlangsungan proses pemasaran yang akan dilakukan. Berdasarkan diskusi yang berlangsung, salah satu permasalahan yang dihadapi peserta yang telah memulai memasarkan produk madunya adalah ketidakyakinan konsumen terhadap keaslian dari produk yang dihasilkan karena memiliki tekstur dan rasa yang berbeda dari produk sejenis yang umumnya beredar di pasaran.

Adanya perbedaan rasa maupun tekstur dari setiap jenis produk madu sangat wajar karena faktor-faktor lingkungan seperti jenis pakan, suhu penyimpanan (Wulandari 2017), dan wilayah 
geografi (Savitri et al. 2017) dapat memengaruhi kualitas produk madu yang dihasilkan. Maka dari itu, masalah ketidakyakinan konsumen yang timbul karena perbedaan karakteristik dari suatu produk madu dapat dihindari dengan melakukan branding produk tanpa harus menyamakan dengan produk sejenis yang telah ada. Branding produk tersebut akan lebih baik apabila didukung dengan kajian ilmiah yang tervalidasi. Sebelumnya, Syaifudin dan Normagiat (2020) pernah menyebutkan salah satu masalah utama yang dihadapi oleh peternak madu Kelulut (Trigona sp.) di Kalimantan Barat juga terkait dengan pemasaran dan branding produk. Branding produk bisa dilakukan dengan memperhatikan komponen dari produk yang meliputi keanekargaman produk, kualitas, desain, bentuk, nama merek, ukuran, pelayanan, dan garansi. Brand image dari suatu produk dapat memengaruhi keputusan pembelian dari konsumen (Prasetya et al. 2018).

Kondisi pandemi yang terjadi saat ini menyebabkan pemasaran secara konvensional cenderung sulit dilakukan sehingga strategi pemasaran lebih mengarah pada pemasaran secara digital. Pemasaran secara digital atau digital marketing merupakan satu cara untuk memper-kenalkan dan memasarkan sebuah produk atau jasa ke masyarakat dengan memanfaatkan media digital/online. Pemanfaatan digital marketing dapat memperluas cakupan target usaha serta dapat menunjang kegiatan penjualan yang lebih baik lagi. Maraknya media online seperti e-commerce dapat menjadi alternatif untuk dapat menjual produk olahan lebah dan sampah rumah tangga ke masyarakat luas. Namun sebelum melakukan pemasaran produk secara online, peserta perlu mengetahui strategi dalam digital marketing. Terdapat enam strategi digital marketing yaitu content marketing, mobile marketing, continous marketing, integrated digital marketing, visual marketing, dan personalized marketing.

Selain penjelasan terkait enam strategi tersebut, peserta juga diberikan beberapa tips dan trick dalam memanfaatkan digital marketing. Pelatihan pemanfaatan digital marketing dalam pengembangan pemasaran dan kewirausahaan UMKM pernah dilakukan di beberapa daerah sebelumnya seperti di Kota Sawahlunto (Farell et al. 2019), Banjarmasin (Naimah et al. 2020), Bandung (Priyatna et al. 2020), dan Jatinangor (Susanti 2020). Hasil pelatihan tersebut mampu menumbuhkan ide-ide kreatif dari pesertanya sehingga mampu memanfaatkan media digital yang ada dan menghasilkan cara pemasaran yang memiliki daya saing.

Selain pemasaran, hal lain yang tidak kalah penting untuk diperhatikan adalah kualitas pelayanan. Kualitas pelayanan tersebut tidak hanya terkait pada kualitas produk yang diberikan namun juga layanan lain seperti keamanan pengemasan, kecepatan pengiriman, serta kecepatan dan sikap dalam menanggapi keluhan dari pelanggan. Pemberian kualitas pelayanan yang baik dapat meningkatkan tingkat kepuasan dan loyalitas dari pelanggan (Gofur 2019). Diskusi yang dilakukan antara peserta dengan narasumber membahas mengenai cara membangun pengaruh terhadap konsumen melalui testimoni/ tanggapan dari produk. Tanggapan konsumen terhadap suatu produk akan muncul setelah konsumen menggunakan atau merasakan produk. Tanggapan positif maupun negatif dari konsumen sebaiknya tetap diterima dengan baik. Tanggapan positif bisa jadi memberikan pengaruh positif yang dapat menarik konsumen baru. Namun, tanggapan negatif juga tidak kalah penting karena dapat menjadi bahan evaluasi untuk peningkatan baik kualitas produk maupun layanan. Adanya perubahan ke arah yang lebih baik sebagai respon terhadap tanggapan negatif, secara tidak langsung juga dapat membangun kepercayaan konsumen bahwa pelaku usaha terus melakukan perbaikan.

\section{Evaluasi dan Keberlanjutan}

Evaluasi kegiatan dilakukan dengan cara membagikan formulir evaluasi kegiatan workshop melalui laman google form kepada peserta di akhir setiap sesi. Data evaluasi yang didapatkan dari formulir tersebut antara lain tingkat kepuasan peserta terhadap materi yang disampaikan, metode pembicara dalam menyampaikan materi, materi yang disajikan, kesesuaian materi dalam penerapan sehari-hari, tingkat kebermanfaatan kegiatan bagi peserta, dan kepuasan peserta secara umum mengenai kegiatan workshop. Peserta juga dapat memberikan kritik dan saran untuk kegiatan workshop selanjutnya.

Tingkat kepuasan peserta terhadap materi yang disampaikan, metode pembicara dalam menyampaikan materi, kemudahan materi untuk dipahami, dan kualitas workshop secara umum disajikan dalam rentang nilai 1 sampai 5 dengan rincian tidak puas, kurang puas, netral, cukup puas, dan sangat puas. Tingkat kebermanfaatan acara bagi peserta disajikan dalam rentang nilai 1 sampai 5 dengan rincian tidak bermanfaat, kurang bermanfaat, netral, cukup bermanfaat, dan sangat bermanfaat. Penilaian kesesuaian materi workshop untuk dapat diterapkan sehari-hari diberikan dalam pilihan ya, tidak, atau mungkin. Hasil evaluasi ditunjukkan pada Gambar 5.

Data evaluasi yang didapatkan dari masingmasing seri kemudian dirata-rata. Nilai rata-rata tersebut dikategorikan berdasarkan rumus interval kelas yaitu: 


$$
\mathrm{c}=\frac{X \max -X \min }{k}
$$

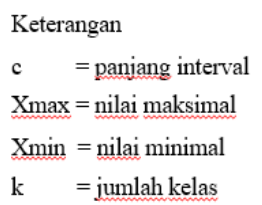

sehingga didapatkan lima kategori sebagai berikut:
$1,00-1,80$ sangat tidak puas
$1,81-2,60$ tidak puas
$2,61-3,40$
biasa
$3,41-4,20$
puas/netral
$4,21-5,00$

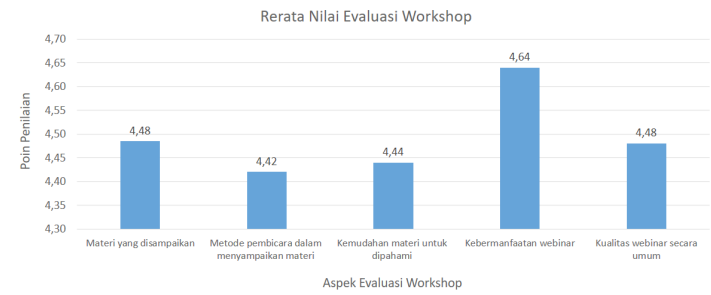

Gambar 5. Rerata nilai evaluasi kegiatan workshop oleh peserta

Gambar 5 menunjukkan bahwa rata-rata nilai secara keseluruhan berada dalam interval 4,215,00 dengan kriteria sangat puas untuk materi yang disampaikan $(4,48)$, metode pembicara dalam menyampaikan materi $(4,42)$, kemudahan materi untuk dipahami $(4,44)$, dan kualitas webinar secara umum $(4,48)$. Workshop dari tiap seri juga dinilai sangat bermanfaat bagi peserta dengan rerata nilai 4,64 .

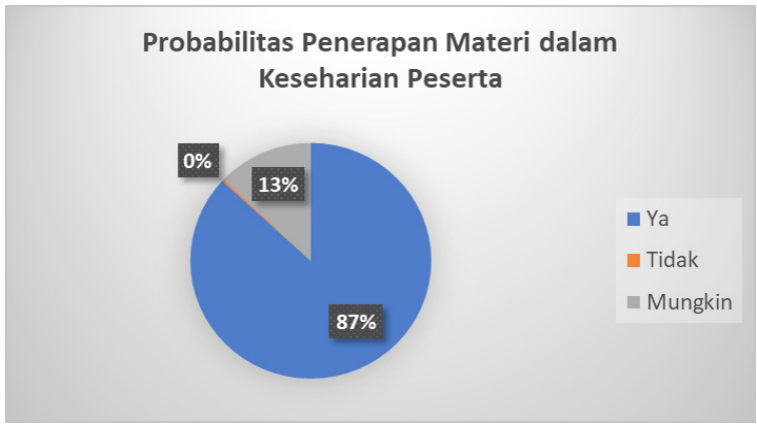

Gambar 6. Persentase probabilitas penerapan materi dalam keseharian peserta.

Mayoritas peserta menilai bahwa materi workshop yang disampaikan dapat diterapkan dalam kehidupan sehari-hari sesuai dengan pengetahuan yang dimiliki, yaitu 87\% menjawab "Ya". (Gambar 6). Sedangkan $13 \%$ lainnya memilih mungkin dapat diterapkan dalam kehidupan sehari-hari, dan $0 \%$ memilih tidak dapat diterapkan dalam kehidupan sehari-hari. Hal ini berkaitan dengan profesi peserta yang sebagian besar berkaitan dengan tema workshop sehingga telah memiliki pengetahuan untuk dapat menerapkan materi workshop.
Secara umum, workshop berlangsung dengan baik dan lancar sesuai dengan perencanaan acara. Kendala minor yang dialami yaitu gangguan sinyal dan audio narasumber yang sangat dipengaruhi oleh lokasi dan cuaca, mengingat workshop dilaksanakan secara daring. Peserta workshop juga berasal dari berbagai daerah di Indonesia yang tentunya sangat memengaruhi kualitas sinyal dan kejernihan gambar serta audio yang dihasilkan. Panitia juga telah menyediakan pranala rekaman workshop apabila di kemudian hari peserta ingin mendengarkan ulang materi yang telah disampaikan oleh narasumber.

Terkait dengan keberlanjutan (sustainability) dari program pengabdian yang dilakukan, sampai saat ini, para peserta masih aktif berkomunikasi dalam grup media komunikasi Whatsapp yang telah dibuat oleh panitia. Tidak hanya peserta, dalam grup tersebut juga bergabung narasumber workshop, sehingga diskusi terkait pembudidayaan lebah dan pengelolaan sampah masih aktif berlangsung. Latar belakang bidang pekerjaan dan tingkat pengalaman peserta yang beragam menyebabkan diskusi bersifat dinamis. Kegiatan workshop mendapatkan reaksi yang positif dari peserta sehingga terdapat saran untuk diselenggarakan workshop lanjutan mengenai pembudidayaan lebah dan pengolahan sampah terutama bagi peserta yang masih pemula, dengan harapan kegiatan workshop lanjutan dapat dilaksanakan secara luring di masa mendatang.

Faktor pendukung kegiatan ini diantaranya adalah adanya panitia dan narasumber dari berbagai disiplin ilmu sehingga dapat memberikan informasi yang menyeluruh, tidak hanya akademisi tetapi juga praktisi; adanya media daring sehingga dapat diikuti oleh peserta di berbagai wilayah Indonesia, disediakannya modul pelatihan sehingga dapat dipelajari oleh peserta; serta waktu kegiatan workshop yang dilakukan secara berturut-turut dalam rentang waktu satu bulan sehingga materi dapat diserap lebih optimal. Sedangkan faktor penghambat adalah koneksi internet yang tidak stabil pada peserta selama workshop berlangsung. Ke depan diharapkan program lanjutan seperti pendampingan budidaya lebah dan pengolahan sampah secara langsung dapat dilakukan. Integrasi budidaya lebah dan pengolahan sampah juga dapat dikembangkan dalam bentuk eduwisata bagi masyarakat. Di sisi lain, kegiatan pengabdian masyarakat serupa yang melibatkan narasumber multidisiplin dapat diduplikasi pada program lainnya.

\section{SIMPULAN}

Program pengabdian masyarakat berupa workshop pemanfaatan lebah dan sampah untuk meningkatkan ekonomi rumah tangga yang berkelanjutan telah 
dilaksanakan dan mendapatkan respons positif dari peserta, terlihat dari jumlah dan asal peserta (171 orang dari berbagai daerah di Indonesia), tingkat kepuasan peserta (sangat puas, rentang 4,21-5,00), dan persentase rencana implementasi hasil workshop (87\%). Program ini dilakukan oleh tim pengabdi multidisiplin. Program serupa dapat diduplikasi dalam program lainnya sehingga penyampaian materi dapat komprehensif dari berbagai latar belakang keilmuan. Adanya forum komunikasi antara peserta dan narasumber setelah workshop dapat menunjang keberlanjutan pemahaman peserta sehingga budidaya lebah dan pengolahan sampah dapat terus diimplementasikan dan dikembangkan.

\section{UCAPAN TERIMAKASIH}

Kami mengucapkan terima kasih kepada Direktorat Pengabdian dan Pemberdayaan Masyarakat Universitas Indonesia atas Hibah PPM Multidisiplin 2020 no. 740/UN2.PPM/HKP.05.00/2020.

\section{DAFTAR PUSTAKA}

Dwiranti, A., Purwanti, D., Putrika, A., Ramadhani, N. T., dan Tohari, H. M. (2019). "Buruken" the New Type of Waste Bank to Support Electricity Sustainability in Sarimukti Village, Garut. $2^{\text {nd }}$ International Conference on Community Service Programme, Universitas PGRI Semarang, 78-83.

Eroglu, U.B.O. danYuksel, S. (2020). Historical Development and Current Status ofBeekeping in Turkey and the World. ATLAS International Refereed Journal on Social Sciences. 6 (27) 345-354.

Fadlil, M. (2021). Konsumsi Madu Meningkat Sejak Pandemi. (http://mataairradio.com/berita-top/ konsumsi-madu-meningkat-sejak-pandemi, diakses 7 Februari 2021)

Fadhilah, R. dan Rizkika K. (2015). Profit of Stingless Bee. (http://www.trubus-online.co.id, diakses 7 Februari 2021).

Farell, G., Thamrin, dan Novid, I. (2019). Pelatihan Pemanfaatan Digital Marketing dalam Pengembangan Pemasaran dan Kewirausahaan UKM pada Kota Sawahlunto, Suluah Bendang. Jurnal Ilmiah Pengabdian Kepada Masyarakat. 19 (1) 42-47.

Gofur, A. (2019). Pengaruh Kualitas Pelayanan dan Harga terhadap Kepuasan Pelanggan. Jurnal Riset Manajemen dan Bisnis (JRMB) Fakultas Ekonomi UNIAT. 4 (1) 37-44.
Halim, E., Hardiansyah, N., Sitandyo, A., Sulaeman, M., Artika, dan Harahap, Y. (2012). Kajian Bioaktif dan Zat Gizi Propolis Indonesia dan Brasil. Jurnal Gizi dan Pangan. 7 (1)1-6.

Kementrian kehutananan, Badan Penelitian dan Pengembangan Kehutanan, Balai Penelitian Teknologi Serat Tanaman Hutan. (2012). Roadmap Penelitian Perlebahan. Riau: Kementrian Kehutanan.

Kingsnorth, S. (2016). Digital Marketing Strategy: An Integrated Approach to Online Marketing. Philadelphia: Kogan Page.

Lamerkabel, J.S.A. (2011). Mengenal jenisjenis lebah madu, produk-produk dan cara budidayanya. LOGIKA Jurnal Ilmu Pengetahuan dan Teknologi. 9 (1) 70-78.

Loeis, T.K. (2019). Keanekaragaman Polen Pakan Lebah tidak Bersengat (Tegraganula aff. minor) di Kampus Universitas Indonesia Depok. Skripsi. Departemen Biologi, Fakultas Matematika dan Ilmu Pengetahuan Alam. Depok: Universitas Indonesia.

Naimah, R. J., Wardhana, M.W., Haryanto, R., dan Pebriyanto, A. (2020). Penerapan Digital Marketing sebagai Strategi Pemasaran UMKM. Jurnal Impact: Implementation and Action. 2 (2).

Prasetya, E.G., Yulianto, E., dan Sunarti. (2018). Pengaruh Brand Image terhadap Keputusan Pembelian (Survei pada Mahasiswa Fakultas Ilmu Administrasi Bisnis Program Studi Administrasi Bisnis Angkatan 2014 Konsumen Air Mineral Aqua). Jurnal Administrasi Bisnis. 62 (2) 214-221.

Pratami, D.K., Mun'im, A., Sundowo, A., dan Sahlan, M. (2018). Phytochemical Profile and Antioxidant Activity of Propolis Ethanolic Extract from Tetragonula Bee. Pharmacognosy Journal. 10 (1) 128-135.

Priyatna, C.C., Prastowo, F.X.A.A., dan Syuderajat, F. (2020). Digital Marketing untuk Usaha Mikro Kecil Menengah (Studi kasus pada Coffeestrip Bandung). Dharmakarya. 9 (4) 283-288.

Putra, N.S., Watiniasih, N.L., dan Suartini, M. (2016). Jenis lebah Trigona (Apidae: Meliponinae) pada Ketinggian Tempat Berbeda di Bali. Jurnal Simbiosis. IV (1) 6-9.

Sadam, B., Hariani, N., dan Fachmy, S. (2016). Jenis Lebah Madu tanpa Sengat (stingless bee) di Tanah Merah Samarinda. Prosiding Seminar Tugas Akhir FMIPA UNMUL. 374-378. 
Savitri, N.P.T., Hastuti, E.D., dan Suedy, S.W.A. (2017). Kualitas Madu Lokal dari Beberapa Wilayah di Kabupaten Temanggung. Buletin Anatomi dan Fisiologi. 2 (1) 58-66.

Sebayang, T., Salmiah, dan Ayu, S.F. (2017). Budidaya Ternak Lebah di Desa Sumberejo, Kecamatan Merbau, Kabupaten Deli Serdang. Abdimas Talenta. 2 (2) 168-178.

Suheryanto, Mara, A., Madjid, A., dan Wijaya, K. (2012). Pemberdayaan Komunitas (Community Empowerment) Petani Kelapa Sawit Ogan Komering Ilir (OKI) Secara Berkelanjutan Melalui Keluarga Mandiri Energi (KME) Berbasis Energi Baru dan Terbarukan (EBT). Dharmakarya. 1 (2) 133137.
Susanti, E. (2020). Pelatihan Digital Marketing dalam Upaya Pengembangan usaha Berbasis Teknologi pada UMKM di Desa Sayang Kecamatan Jatinangor. Sawala. 1 (2) 36-50.

Susilo, B.N.M., Mertaniasih, Koendhori, E.B., dan Agil, M. (2009). Komposisi Kimiawi dan Aktivitas Antimikroba Propolis dari Malang Jawa Timur. Jurnal Penelitian Medika Eksakta. 8 (1) 23-30.

Syaifudin, S.M. dan Normagiat, S. (2020). Budidaya Pakan Lebah Trigona sp. dengan Apiculture Agroforestry System di Kelurahan Anjungan Melancar Kabupaten Mempawah. Jurnal Ilmiah Pengabdhi. 6 (1) 17-24.

Wulandari, D.D. (2017). Kualitas Madu (Keasaman, Kadar Air, Dan Kadar Gula Pereduksi) Berdasarkan Perbedaan Suhu Penyimpanan. Jurnal Kimia Riset. 2 (1) 16-22. 